\title{
PENINGKATAN PRESTASI BELAJAR SISWA PADA MATA PELAJARAN BAHASA INDONESIA TENTANG PERCAKAPAN LEWAT TELEPON ATAU ALAT KOMUNIKASI SEDERHANA (Melalui Metode Pemberian Tugas Kelas IV MI No. 25/E.3 Ambai Bawah Tahun Ajaran 2017/2018)
}

\author{
Citra Dewi \\ Guru MI No. 25/e.3 Ambai Bawah Kabupaten Kerinci \\ Email: citrad643@gmail.com
}

\begin{abstract}
Abstrak
Ada peningkatan yang signifikan pada penguasaan materi pembelajaran, hal ini dapat dibuktikan dari hasil tes formatif pada siklus I, siklus II, dan siklus III. Pada siklus III ada 23 siswa dari jumlah 26 siswa atau sebesar 88,46\% yang memperoleh nilai $\geq 65$. Ini berarti batas tuntas belajar telah terpenuhi karena jumlah siswa yang memperoleh nilai $\geq 65$ lebih dari $75 \%$.

Dengan adanya tindakan perbaikan pembelajaran ini, motivasi siswa untuk memahami dan menguasai materi pelajaran sangat tinggi, hal ini dapat dilihat dari hasil belajar siswa yang diperoleh dari siklus I, siklus II dan siklus III. Di samping itu menumbuhkan sikap siswa untuk meningkatkan belajarnya, berani mengungkapkan pendapat atau bertanya serta tidak ragu-ragu lagi dalam menghadapi berbagai persoalan materi pelajaran.
\end{abstract}

\section{Kata Kunci : Prestasi Belajar, Bahasa Indonesia, Alat Komunikasi}

\section{A. PENDAHULUAN}

\section{Latar Belakang Masalah}

Pendidikan adalah usaha sadar untuk mewujudkan suasana belajar dan proses pembelajaran agar peserta didik secara aktif mengembangkan potensi dirinya untuk memiliki kekuatan spiritual keagamaan, pengendalian diri, kepribadian, kecerdasan, akhlak mulia, serta keterampilan yang diperlukan dirinya, masyarakat, bangsa dan negara (Depdikbud, 2003:9).

Lahirnya undang-undang No. 20 Tahun 2003 tentang Sistim Pendidikan nasional telah membawa dampak positif bagi pembelajaran bahasa Indonesia. Hal ini mencerminkan dengan diangkat membaca, menulis dan berhitung sebagai kemampuan dasar berbahasa yang secara dini dan berkesinambungan menjadi perhatian dan kegiatan di sekolah dasar. 
Peningkatan mutu pendidikan pada setiap jenis dan satuan pendidikan terutama satuan pendidikan dasar merupakan komitmen nasional dan titik berat pembangunan pendidikan pada saat ini dan pada kurun waktu yang akan datang (Depdikbud, 1994:V). Untuk meningkatkan mutu pendidikan di daerah, seorang guru harus memperhatikan kondisi siswa, orang tua siswa, lingkungan dan latar belakang siswa.

Menurut Umar (2000:84) bahwa guru MI wajib mengetahui latar belakang kehidupan anak, agar guru MI dapat memprediksikan perkembangan bahasa dan pemerolehan bahasa anak. Informasi mengenai perkembangan dan pemerolehan bahasa anak menjadi pertimbangan penyusunan program mengajar.

Dalam proses pembelajaran bahasa Indonesia, seringkali terjadi bahwa tidak semua siswa dapat menyerap dan memahami materi pada saat pertama kai diajarkan. Hal tersebut terjadi karena setiap siswa memang memiliki potensi dan karakter yang berbeda. Jika di sekolah dasar tidak dimatangkan tentang kebahasan, dikhawatirkan nanti di kelas yang lebih tinggi siswa tidak dapat mengikuti pelajaran yang lain. Karena mata pelajaran bahasa Indonesia sangatlah penting, sebab dengan keterampilan bahasa siswa dapat mengikuti mata pelajaran yang lain seperti PKn, pendidikan agama, matematika, ilmu pengetahuan alam, dan ilmu pengetahuan sosial. Keberhasilan guru pada mata pelajaran bahasa Indonesia dalam menjalankan tugasnya sangat dipengaruhi oleh pelaksanaan proses pembelajaran di kelas. Oleh sebab itu, guru sebaiknya menyiapkan diri dalam menyajikan bahan pembelajaran, menentukan kegiatan yang akan dilakukan bersama dengan siswa, mengupayakan agar bahan dan sajiannya dapat tercapai, penunjang yang sesuai dengan bahan yang diajarkan, sehingga dapat tercapai tujuan pembelajaran yang diharapkan.

Dalam penelitian ini menggunakan desain penelitian tindakan kelas yang ditempuh dalam tiga siklus, yaitu siklus I, siklus II, dan siklus III. Masing-masing terdiri dari empat tahap atau langkah-langkah, yaitu : (1) perencanaan (2) tindakan, (3) pengamatan, (4) refleksi. Keempat langkah tersebut selalu berkaitan antara satu dengan yang lain. Begitu pula pelaksanaannya, antara siklus I, siklus 
II, dan siklus III saling berkaitan. Siklus III merupakan penyempurnaan dari siklus II, dan siklus II penyempurnaan dari kelemahan dan kekurangan pada siklus I.

Demikian juga yang terjadi pada mata pelajaran Bahasa Indonesia kelas IV MI No. 25/E.3 Ambai Bawah Tahun Pelajaran 2017/2018 pada materi percakapan lewat telepon atau alat komunikasi sederhana, ternyata nilainya masih rendah, terbukti dari 26 siswa yang mendapat nilai tuntas belajar hanya 12 siswa. Untuk itu peneliti melaksanakan perbaikan pembelajaran melalui penelitian tindakan kelas.

\section{Rumusan Masalah}

Berdasarkan latar belakang di atas, rumusan masalah yang menjadi fokus perbaikan adalah "Apakah metode pemberian tugas dapat meningkatkan prestasi belajar siswa terhadap mata pelajaran Bahasa Indonesia tentang percakapan lewat telepon atau alat komunikasi sederhana pada siswa kelas IV MI No. 25/E.3 Ambai Bawah Kabupaten Kerinci Tahun Pelajaran 2017/2018?”.

\section{Tujuan Penelitian}

Berdasarkan rumusan masalah di atas, tujuan penelitian ini adalah :

a. Mendeskripsikan kemampuan siswa dalam pembelajaran Bahasa Indonesia tentang percakapan lewat telepon atau alat komunikasi sederhana melalui metode tugas pada siswa kelas IV MI No. 25/E.3 Ambai Bawah Kabupaten Kerinci.

b. Mendeskripsikan prestasi belajar siswa kelas IV MI No. 25/E.3 Ambai Bawah Kabupaten Kerinci pada mata pelajaran Bahasa Indonesia tentang percakapan lewat telepon atau alat komunikasi sederhana melalui metode pemberian tugas.

c. Untuk meningkatkan pemahaman siswa terhadap pembelajaran Bahasa Indonesia tentang percakapan lewat telepon atau alat komunikasi sederhana dengan menggunakan metode tugas pada siswa kelas IV MI No. 25/E.3 Ambai Bawah Kabupaten Kerinci. 


\section{Manfaat Penelitian Perbaikan Pembelajaran}

a. Bagi Guru

- Dapat meningkatkan efektifitas pembelajaran bahasa Indonesia tentang percakapan lewat telepon atau alat komunikasi sederhana.

- Menemukan masalah yang timbul dalam proses pembelajaran bahasa Indonesia tentang percakapan lewat telepon atau alat komunikasi sederhana.

b. Bagi Siswa

- Meningkatkan minat belajar siswa pada mata pelajaran Bahasa Indonesia tentang percakapan lewat telepon atau alat komunikasi sederhana.

- Siswa berani bertanya dan menjawab pertanyaan pada mata pelajaran Bahasa Indonesia tentang percakapan lewat telepon atau alat komunikasi sederhana.

- Siswa lebih bersemangat dalam mengikuti pembelajaran Bahasa Indonesia pada pokok bahasan percakapan lewat telepon atau alat komunikasi sederhana.

- Berani mengemukakan pendapat

- Melatih siswa belajar berpikir kritis, kreatif, analitis dan sistematis

c. Bagi Sekolah

- Meningkatkan efektivitas pembelajaran di sekolah

- Meningkatkan mutu pendidikan bagi sekolah

- Sebagai rujukan bagi sekolah lain untuk meningkatkan proses pembelajaran yang efektif demi tercapainya prestasi belajar.

\section{B. KAJIAN PUSTAKA}

\section{Pembelajaran Bahasa Indonesia}

Pembelajaran bahasa diharapkan membantu peserta didik mengenal dirinya, budayanya, mengemukakan gagasan dan perasaan berpartisipasi dalam masyarakat yang menggunakan bahasa tersebut dan menemukan serta menggunakan kemampuan analitis dan imajinatif. Pembelajaran Bahasa Indonesia bertujuan agar peserta didik memiliki kemampuan kebahasaan, penguasaan pengetahuan, pemahaman, dan penggunaan atau keterampilan (Depdiknas, 
2006:317). Untuk mencapai kompetensi hasil belajar Bahasa Indonesia di MI yang telah dirumuskan secara nasional, maka pembelajaran Bahasa Indonesia dikembangkan melalui empat aspek keterampilan utama Bahasa Indonesia (mendengarkan, berbicara, membaca dan menulis) dan dua aspek keterampilan penunjang yakni kebahasaan dan apresiasi bahasa dan sastra Indonesia, yang dalam pelaksanaannya aspek-aspek itu dijadikan fokus dalam setiap pertemuan.

Pada dasarnya keempat aspek keterampilan berbahasa merupakan satu kesatuan yang tak terpisahkan dan ditunjang oleh dua aspek lainnya. Hal ini dapat dilihat dari hubungan berikut, mula-mula seseorang belajar bahasa dengan menyimak, bahasa yang didengarnya dari lingkungan, kemudian berbicara. Sesudah itu, melalui pendidikan formal, seseorang baru belajar membaca dan menulis. Berarti bahasa seseorang mencerminkan pikirannya dan keterampilan berbahasa diperoleh melalui praktik/latihan, yang berarti juga melatih keterampilan berpikir (Tarigan, 1984 : 87).

Tujuan umum pembelajaran bahasa Indonesia di MI adalah (1) siswa menghargai dan membanggakan Bahasa Indonesia sebagai bahasa persatuan dan bahasa negara, (2) berkomunikasi secara efektif dan efisien sesuai dengan etika yang berlaku, baik secara lisan maupun tulis, (3) memahami bahasa Indonesia dan menggunakannya dengan tepat dan kreatif untuk berbagai tujuan, (4) menggunakan Bahasa Indonesia untuk meningkatkan kemampuan intelektual, serta kematangan emosional dan sosial, (5) menikmati dan memanfaatkan karya sastra untuk memperluas wawasan, memperhalus budi pekerti, serta meningkatkan pengetahuan dan kemampuan berbahasa (6) menghargai dan membanggakan sastra Indonesia sebagai khasanah budaya dan intelektual manusia Indonesia (Depdiknas, 2006:318).

\section{Metode Tugas}

Pasaribu (1986:108) menjelaskan metode tugas adalah suatu metode dalam pembelajaran dengan jalan memberikan tugas pada siswa untuk berpikir secara kongkrit terhadap bahan pelajaran yang telah diberikan. Sedangkan Ali memberikan batasan metode tugas adalah cara belajar atau mengajar yang

VOLUME 2, NO. 1 Juli - Desember 2019 
menekankan pada pemberian tugas pada siswa agar tercapai sesuai dengan yang diharapkan (Ali, 2005:742).

Pengertian ini bukan berarti hanya untuk mengerjakan tugas bahan-bahan pelajaran yang telah diberikan oleh guru dengan metode ini, tetapi dapat juga digunakan untuk penyampaian bahan pelajaran yang sedang atau akan diajarkan. Peranan metode tugas sangat penting dalam pembelajaran. Metode tugas merupakan suatu aspek dari metode-metode pembelajaran, karena metode tugas bermaksud : meninjau pelajaran baru, untuk menghafal pelajaran yang sudah diajarkan, untuk latihan-latihan, untuk mengumpulkan bahan, untuk memecahkan suatu masalah, dan sebagainya.

Metode tugas dapat dilakukan secara individu, secara kelompok, atau tugas untuk kelas. Tugas dapat digunakan dalam subject kurikulum, atau dapat dalam unit. Metode tugas dapat dilakukan di dalam kelas, dapat di luar kelas, atau di luar jam pelajaran sebagai pekerjaan rumah. Adapun tujuan dalam metode tugas adalah :

a. Memiliki keterampilan berpikir kongkrit, seperti menghafalkan kata-kata, menggunakan tanda-tanda baca dalam menulis.

b. Mengembangkan kecakapan intelektual, seperti mengenal benda/bentuk dalam pelajaran matematika, ilmu pasti, tanda baca, dan sebagainya.

c. Memiliki kemampuan menghubungkan antara suatu keadaan dengan hal lain, seperti hubungan sebab akibat, antara tanda baca dan huruf, penggunaan lambang dalam kalimat (Roestiyah, 1991:125).

Kelebihan metode tugas adalah :

a. Dalam waktu relatif singkat,dapat diperoleh penguasaan dan keterampilan yang diharapkan.

b. Dapat menghadapi kesulitan-kesulitan yang telah dipelajari

c. Tingkat hasil belajar tinggi

d. Akan menanamkan siswa kebiasaan belajar secara runtut dan disiplin.

Adapun kelemahan metode tugas adalah :

a. Kurang memperhatikan penyesuaiannya dengan lingkungan 
b. Membentuk kebiasaan-kebiasaan yang kaku, karena anak mengerjakan tugas dengan terpaksa

c. Kurang menumbuhkan minat dan inisiatif siswa (Pasaribu, 1985:109).

\section{Prestasi Belajar Siswa pada Pembelajaran Bahasa Indonesia}

Prestasi belajar adalah hasil yang diperoleh dari penguasaan pengetahuan dan keterampilan yang dikembangkan melalui mata pelajaran, lazimnya ditunjukkan nilai tes atau angka nilai yang diberikan oleh guru (Ali, 2005:895). Menurut Rusyan (1994:81) prestasi belajar yang dicapai seseorang individu merupakan hasil interaksi antara berbagai faktor yang mempengaruhi baik dari dalam maupun dari luar individu. Prestasi belajar yang dicapai seseorang merupakan hasil interaksi antara berbagai faktor yang mempengaruhi baik eksternal maupun internal. Faktor eksternal diperoleh dari lingkungan baik lingkungan keluarga, lingkungan sekolah maupun lingkungan keluarga. Faktor internal bersumber pada diri siswa itu sendiri yang berupa kecerdasan bakat, minat, motivasi dan penyesuaian diri. Pengenalan terhadap faktor-faktor yang mempengaruhi prestasi penting sekali artinya dalam rangka membantu siswa dalam mencapai prestasi belajar yang sebaik-baiknya (Ahmadi, 1991:130).

Prestasi belajar yang dicapai siswa tergantung pada tingkat potensi (kemampuannya) baik berupa kecerdasan maupun bakat. Siswa yang berpotensi tinggi cenderung memperoleh prestasi belajar yang tinggi dan sebaliknya. Jadi siswa yang mengalami kesulitan belajar adalah siswa yang tidak dapat mencapai prestasi belajar sesuai dengan potensinya.

\section{METODE PENELITIAN}

\section{Subjek, Tempat, dan Waktu Penelitian}

Penelitian tindakan kelas ini dilaksanakan di MI No. 25/E.3 Ambai Bawah Kabupaten Kerinci Tahun Pelajaran 2017/2018, sebagai objek penelitian adalah siswa kelas III semester I yang berjumlah 26 siswa terdiri dari 12 laki-laki dan 14 perempuan. Adapun jadwal pelaksanaan perbaikan pembelajaran Bahasa 
Indonesia dengan materi pokok percakapan lewat telepon atau alat komunikasi sederhana dengan kalimat yang ringkas adalah sebagai berikut :

1. Tanggal 6 April 2018 pelaksanaan siklus I

2. Tanggal 13 April 2018 pelaksanaan siklus II

3. Tanggal 20 April 2018 pelaksanaan siklus III

Dalam pelaksanaan, peneliti dibantu oleh teman sejawat dan kepala sekolah. Teman sejawat membantu mengamati proses pembelajaran sedangkan kepala sekolah membantu memberikan dukungan dalam pelaksanaan perbaikan pembelajaran.

\section{Desain Prosedur Perbaikan Pembelajaran}

Penelitian tindakan kelas ini ditempuh dalam tiga siklus, yaitu siklus I, siklus II dan siklus III. Masing-masing siklus terdiri dari empat tahap atau langkah-langkah yaitu : 1) perencanaan, 2) tindakan, 3) pengamatan, dan 4) refleksi. Keempat langkah tersebut selalu berkaitan antara satu dengan yang lain. Begitu dalam pelaksanaannya saling berkaitan dan siklus III merupakan penyempurnaan dari kelemahan dan kekurangan dari siklus I dan siklus II.

\section{HASIL DAN PEMBAHASAN}

\section{Deskripsi Hasil Penelitian Perbaikan Pembelajaran}

Hasil penelitian ini terdiri atas kondisi awal atau sebelum perbaikan dan hasil penelitian tindakan kelas pada siklus I, siklus II, dan siklus III. Berdasarkan hasil tes formatif sebelum perbaikan pembelajaran Bahasa Indonesia Kelas IV MI No. 25/E.3 Ambai Bawah Kabupaten Kerinci Tahun Pelajaran 2017/2018 adalah sebagai berikut :

Tabel 1 : Rekapitulasi Hasil Tes Sebelum Perbaikan

\begin{tabular}{|l|l|l|l|l|}
\hline No & Skor & Kategori & Frekuensi & Persentasi \\
\hline 1. & $\leq 50$ & Jelek & 8 & $30,77 \%$ \\
2. & $51-65$ & Kurang & 7 & $26,92 \%$ \\
3. & $66-75$ & Cukup & 5 & $19,23 \%$ \\
4. & $76-85$ & Baik & 6 & $23,08 \%$ \\
\hline
\end{tabular}

VOLUME 2, NO. 1 Juli - Desember 2019 


\begin{tabular}{|l|l|l|l|l|}
\hline 5. & $86-100$ & Sangat baik & - & $0 \%$ \\
\hline & JUMLAH & & 26 & $100 \%$ \\
\hline
\end{tabular}

Berdasarkan tabel 1 di atas, dari jumlah 26 siswa hanya ada 6 siswa yang termasuk kategori baik atau sebesar 23,08\%. Nilai antara $66-75$ didapat oleh 5 siswa atau sebesar 19,23\% dalam kategori cukup. Nilai antara 51-65 didapat oleh 7 siswa atau sebesar 26,9\% termasuk dalam kategori kurang, dan nilai kurang dari atau sama dengan 50 didapat oleh 8 siswa atau sebesar $30,77 \%$ termasuk dalam kategori jelek.

Hasil tes formatif sebelum perbaikan tindakan pembelajaran dapat digambarkan dalam diagram batang sebagai berikut :

Gambar 1 : Grafik Hasil Tes Formatif Sebelum Perbaikan

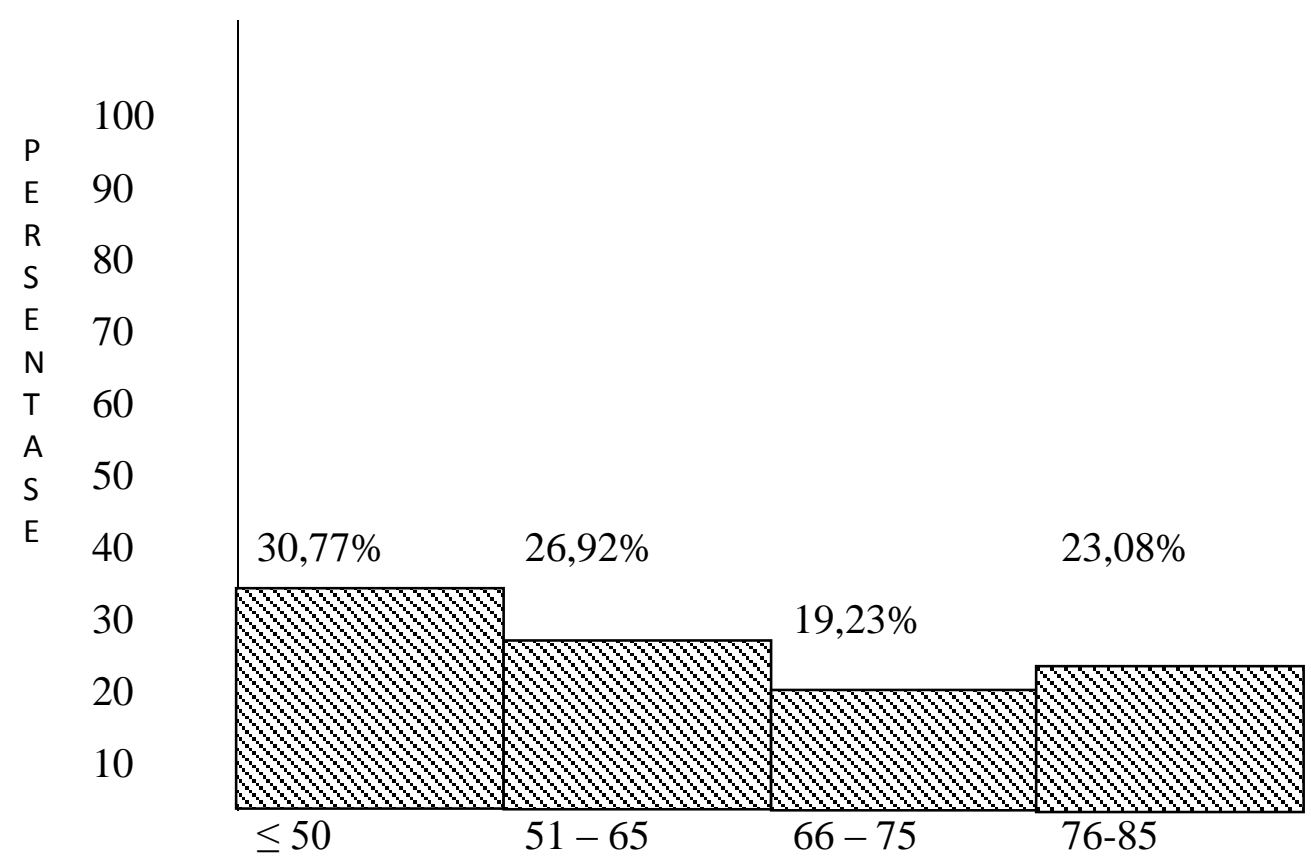

\section{Hasil Tes Siklus I}

Hasil tes formatif penguasaan materi pembelajaran Bahasa Indonesia tentang percakapan lewat telepon atau alat komunikasi sederhana pada siklus I sebagai berikut : 
Tabel 2 : Analisis Hasil Tes Formatif Siklus I

\begin{tabular}{|l|l|l|l|l|}
\hline No & Skor & Kategori & Frekuensi & Persentase \\
\hline 1. & $\leq 50$ & Jelek & 5 & $19,23 \%$ \\
2. & $51-65$ & Kurang & 6 & $23,08 \%$ \\
3. & $66-75$ & Cukup & 8 & $30,77 \%$ \\
4. & $76-85$ & Baik & 7 & $26,92 \%$ \\
5. & $86-100$ & Sangat baik & - & - \\
\hline & Jumlah & & 26 & $100 \%$ \\
\hline
\end{tabular}

Berdasarkan tabel 2 di atas, dari jumlah 26 siswa hanya 15 siswa yang termasuk kategori baik dan kategori cukup sebesar 57,69\% yang melampaui batas ketuntasan belajar. Karena belum memenuhi target yang diharapkan maka perlu mengadakan tindakan perbaikan pembelajaran pada siklus I.

Hasil tes formatif siklus I dapat digambarkan dalam diagram batang sebagai berikut :

Gambar 2 : Grafik Hasil Tes Formatif Perbaikan Siklus I

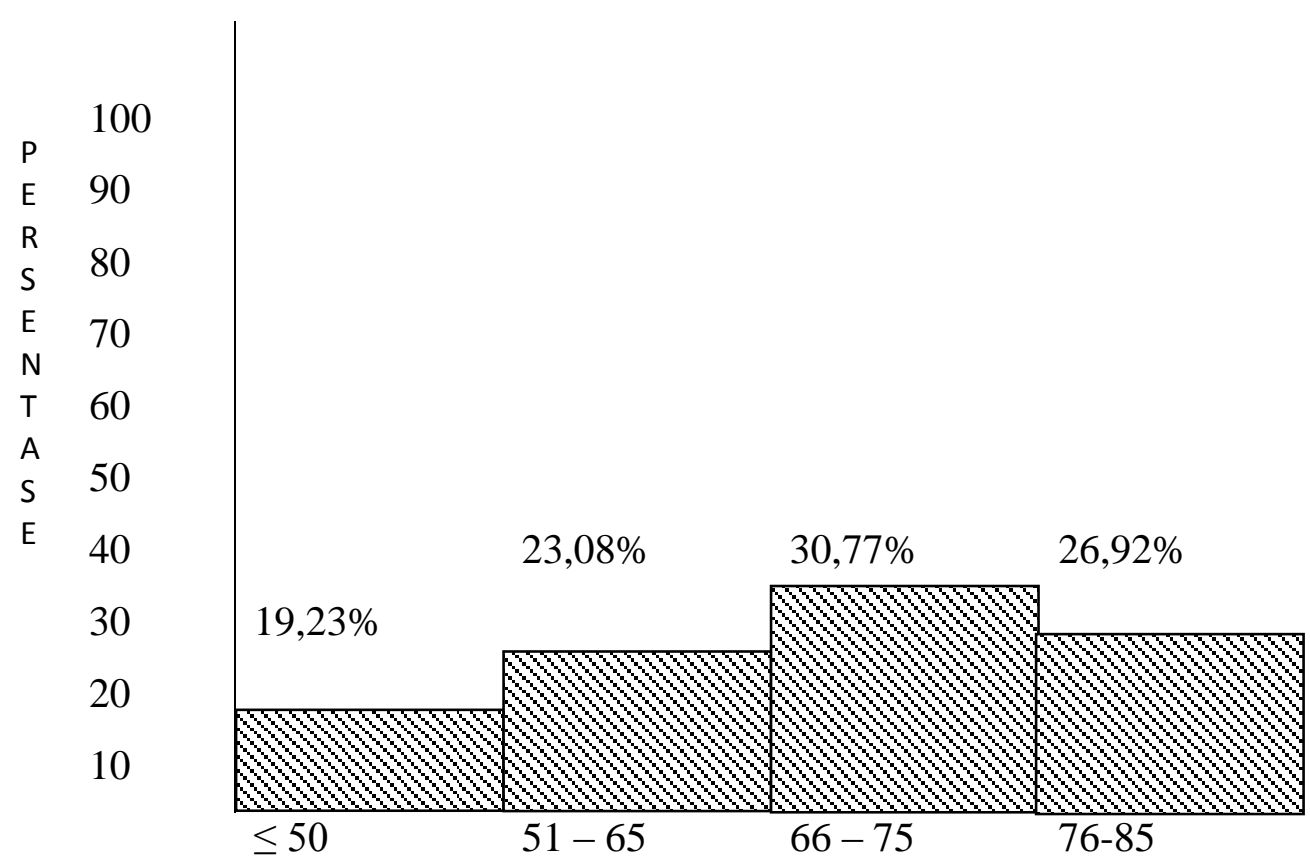

VOLUME 2, NO. 1 Juli - Desember 2019 


\section{Hasil Tes Siklus II}

Hasil tes formatif penguasaan materi pembelajaran Bahasa Indonesia tentang percakapan lewat telepon atau alat komunikasi sederhana pada siklus II sebagai berikut :

Tabel 3 : Analisis Hasil Tes Formatif Siklus II

\begin{tabular}{|l|l|l|l|l|}
\hline No & Skor & Kategori & Frekuensi & Persentase \\
\hline 1. & $\leq 50$ & Jelek & 2 & $7,69 \%$ \\
2. & $51-65$ & Kurang & 5 & $19,23 \%$ \\
3. & $66-75$ & Cukup & 9 & $34,62 \%$ \\
4. & $76-85$ & Baik & 10 & $38,46 \%$ \\
5. & $86-100$ & Sangat baik & - & $-\%$ \\
\hline & Jumlah & & 26 & $100 \%$ \\
\hline
\end{tabular}

Berdasarkan tabel 3 di atas, penguasaan materi pembelajaran Bahasa Indonesia dari jumlah 26 siswa hanya ada 19 siswa yang termasuk kategori baik dan kategori cukup atau sebesar 73,08\% yang melampaui batas ketuntasan belajar. Pada siklus II mengalami peningkatan batas ketuntasan belajar siswa, yang semula 15 siswa atau sebesar 57,69\% menjadi 19 siswa atau sebesar 73,08\%. Karena hasil yang diperoleh belum memenuhi target yang diharapkan, maka diadakan lagi tindakan perbaikan pembelajaran pada siklus III.

Hasil tes formatif perbaikan pembelajaran siklus II dapat digambarkan dalam diagram batang sebagai berikut : 
Gambar 3 : Grafik Hasil Tes Formatif Perbaikan Siklus II

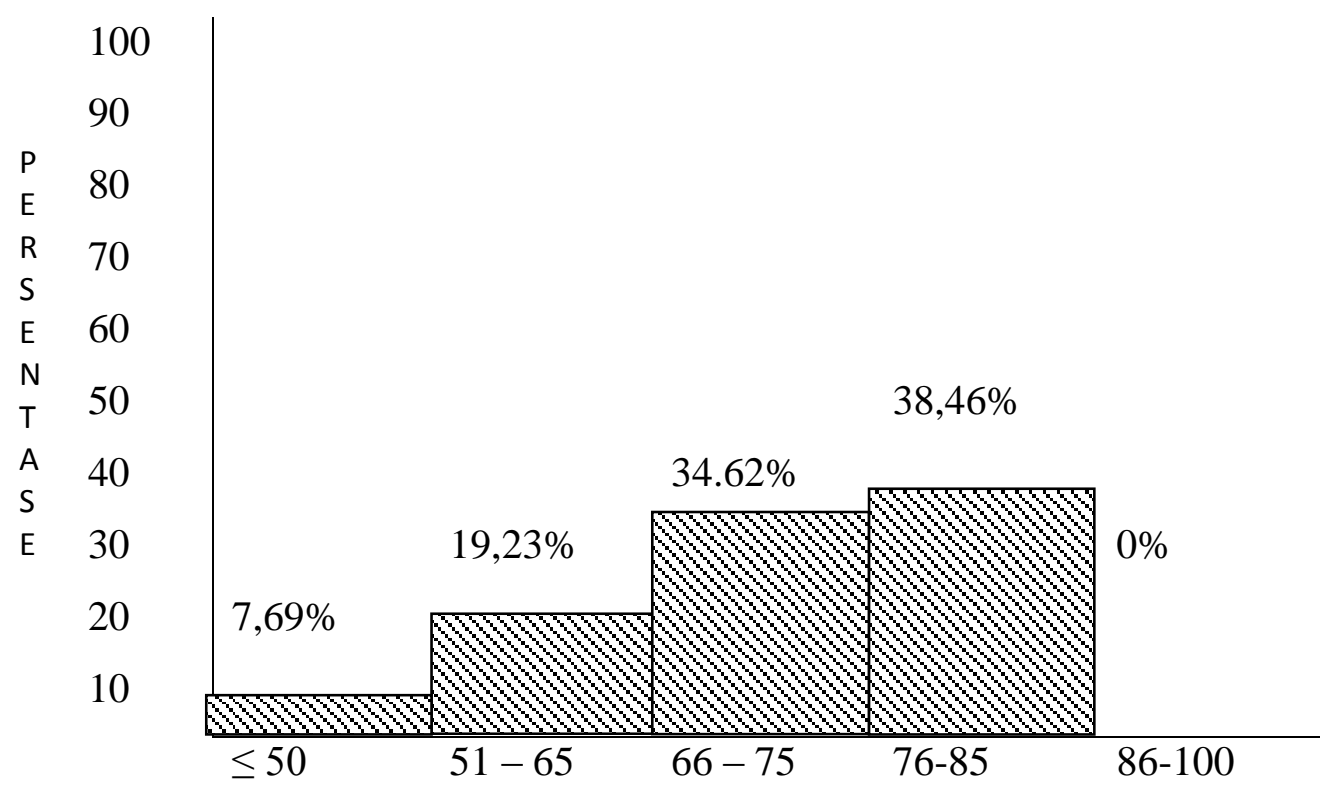

\section{Hasil Tes Siklus III}

Hasil tes formatif penguasaan materi pembelajaran Bahasa Indonesia tentang percakapan lewat telepon atau alat komunikasi sederhanapada siklus III sebagai berikut :

Tabel 4 : Analisis Hasil Tes Formatif Siklus III

\begin{tabular}{|l|l|l|l|l|}
\hline No & Skor & Kategori & Frekuensi & Persentase \\
\hline 1. & $\leq 50$ & Jelek & - & - \\
2. & $51-65$ & Kurang & 3 & $11,53 \%$ \\
3. & $66-75$ & Cukup & 6 & $23,08 \%$ \\
4. & $76-85$ & Baik & 9 & $34,62 \%$ \\
5. & $86-100$ & Sangat baik & 8 & $30,77 \%$ \\
\hline & Jumlah & & 26 & $100 \%$ \\
\hline
\end{tabular}

Berdasarkan tabel 4 di atas, penguasaan siswa pada materi pembelajaran Bahasa Indonesia dari jumlah 26 siswa ada 23 siswa yang mendapat nilai di atas ketuntasan belajar. Keadaan siswa pada siklus III ini 
mengalami peningkatan yang lebih baik, yakni ada 23 siswa atau sebesar $88,46 \%$ dari jumlah 26 siswa yang mendapat nilai $\geq 65$.

Hasil tes formatif perbaikan pembelajaran siklus III dapat digambarkan dalam diagram batang sebagai berikut :

Gambar 4 : Grafik Hasil Tes Formatif Perbaikan Siklus III

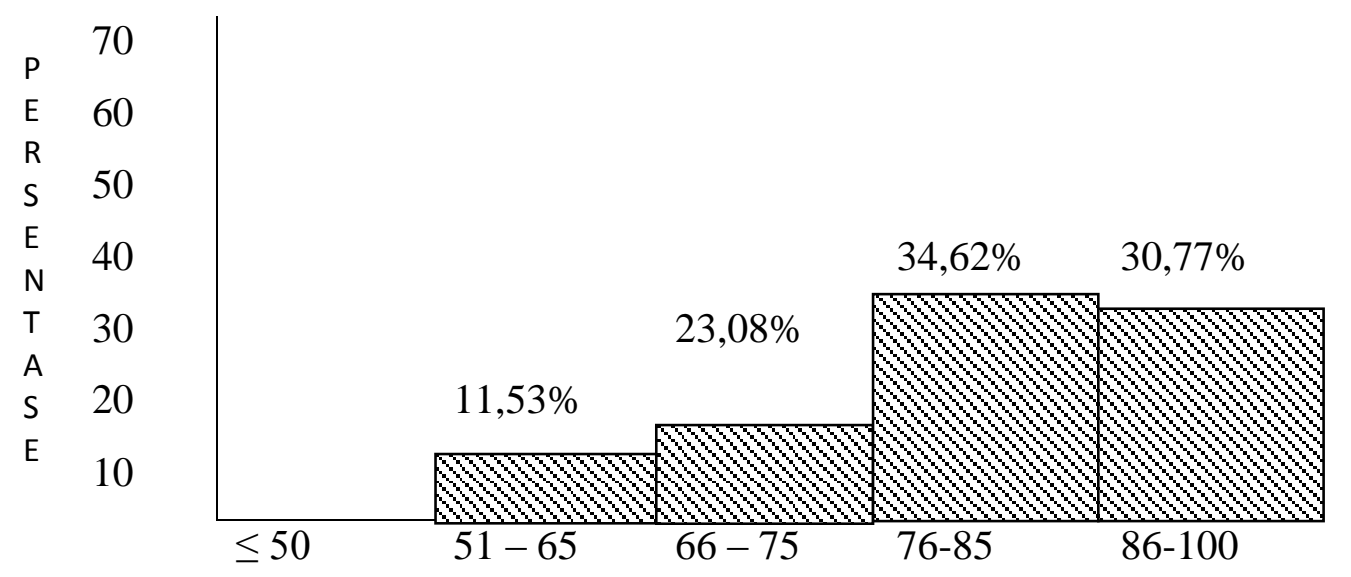

Grafik peningkatan hasil tes formatif mata pelajaran Bahasa Indonesia tentang percakapan lewat telepon atau alat komunikasi sederhana sebelum perbaikan sampai perbaikan siklus I, siklus II, dan siklus III dapat digambarkan dalam diagram batang sebagai berikut :

Gambar 5 : Grafik Hasil Tes Formatif Sebelum Perbaikan, Siklus I, Siklues II dan Siklus III 


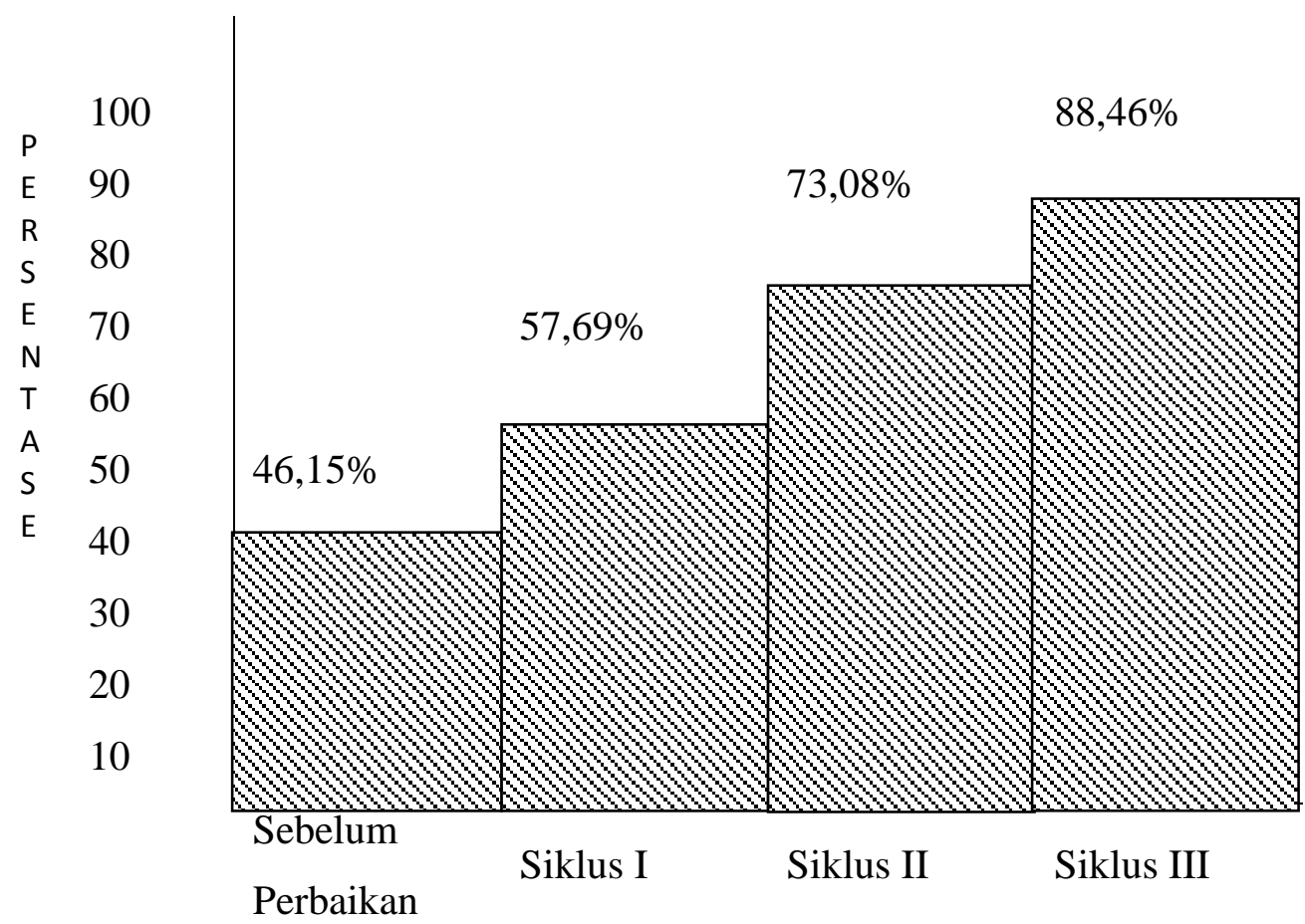

\section{Pembahasan Hasil Penelitian Perbaikan Pembelajaran}

Berdasarkan hasil tes formatif siklus I, dari jumlah 26 siswa hanya ada 7 siswa yang termasuk kategori baik atau sebesar 26,92\% yaitu mereka yang mencapai nilai antara 76-85. Nilai antara 66 sampai 75 didapat oleh 8 siswa atau $30,77 \%$ yaitu mereka yang termasuk kategori cukup. Sementara ada 6 siswa yang mendapat nilai dalam kategori kurang atau sebesar 23,68\% mereka hanya dapat mencapai nilai antara 51-65. Namun ada 5 siswa yang termasuk kategori jelek yang mendapat nilai $\leq 50$ atau sebesar $19,23 \%$.

Hasil tes formatif diatas didukung dengan hasil pengamatan diperoleh data yaitu pada saat proses pembelajaran dilaksanakan, sebagian besar siswa tidak tertarik dengan teknik yang diberikan, hal ini terlihat jelas dari cara siswa merespon terhadap tugas yang diberikan. Siswa bersikap pasif dan tidak berusaha maksimal untuk mengerjakannya. Ada beberapa siswa yang menganggap bahwa tugas yang diberikan itu tidak penting, sehingga siswa kurang berusaha dalam mengerjakannya. Namun demikian ditemukan beberapa siswa yang menganggap serius, yaitu terbukti adanya siswa yang bersungguh-sungguh dalam mengerjakan dan dapat menyelesaikan tugas dengan baik.

VOLUME 2, NO. 1 Juli - Desember 2019 
Pada hasil analisis dan pengamatan proses pembelajaran siklus I menunjukkan hal-hal sebagai berikut : 1) belum seluruh siswa mampu menguasai materi pembelajaran Bahasa Indonesia, 2) sebagian siswa belum memiliki ketertarikan pada materi pembelajaran, 3) motivasi belajar masih kurang, 4) media dan metode pembelajaran belum optimal, 5) kurangnya perhatian siswa pada saat pembelajaran berlangsung, 6) pengelolaan kelas belum sepenuhnya terkendali.

Hasil tes formatif dan pengamatan yang telah dilaksanakan pada siklus I ternyata hasil yang diperoleh belum memenuhi target kategori baik atau mencapai nilai rata-rata 75 sampai 85 . Hal ini terbukti dengan jumlah siswa yang mendapat nilai lebih dari 65 adalah 15 siswa atau sebesar 57,69\% yang melampaui batas tuntas belajar. Karena belum memenuhi target yang diharapkan maka perlu mengadakan tindakan perbaikan pembelajaran pada siklus II.

Berdasarkan hasil tes formatif siklus II, penguasaan materi pembelajaran Bahasa Indonesia dari jumlah 26 siswa ada 10 siswa yang termasuk kategori baik atau sebesar 38,46\%, yaitu mereka yang mencapai nilai antara 76-85. Nilai antara 66-75 didapat oleh 9 siswa atau sebesar 34,62\% yaitu mereka yang termasuk kategori cukup. Sementara ada 5 siswa yang mencapai nilai dalam kategori kurang atau sebesar 19,23\% yaitu nilai antara 51-65. Namun ada juga siswa yang mendapat nilai dengan kategori jelek yaitu 2 siswa atau 7,69\%.

Pada hasil analisis dan pengamatan proses pembelajaran pada siklus II menunjukkan hal-hal sebagai berikut : 1) belum seluruhnya siswa mampu menguasai materi pembelajaran, 2) media dan metode masih belum optimal, 3) hanya sebagian siswa yang mempunyai motivasi belajar yang tinggi.

Hasil tes formatif dan pengamatan yang telah dilaksanakan pada siklus II, hasil yang diperoleh masih belum memenuhi target yang diharapkan maka perlu diadakan lagi perbaikan pembelajaran pada siklus III.

Berdasarkan hasil tes formatif siklus III, penguasaan materi pembelajaran Bahasa Indonesia dari jumlah 26 siswa ada 8 siswa yang termasuk kategori sangat baik atau sebesar 30,77\%, yaitu mereka yang mencapai nilai diatas 86. Nilai antara 76-85 didapat oleh 9 siswa atau sebesar 34,62\% yaitu mereka yang termasuk kategori baik. Sementara ada 6 siswa yang mencapai nilai dalam 
kategori cukup atau sebesar 23,08\% yaitu nilai antara 66-75. Namun masih ada tiga siswa yang mencapai nilai dalam kategori kurang atau sebesar 11,53\% yaitu mereka yang mencapai nilai 51-65.

Hasil tes formatif penguasaan materi pembelajaran Bahasa Indonesia pada siklus III diatas, didukung dengan hasil pengamatan terhadap siswa pada waktu proses pembelajaran berlangsung sebagian besar siswa memiliki antusias dan motivasi belajar yang tinggi. Ada sebagian kecil siswa yang terlihat pasif namun ketidakaktifan siswa tersebut disebabkan oleh situasi dan kondisi siswa itu sendiri. Pada siklus III ini mengalami peningkatan yang tinggi, karena hasil tersebut pada siklus II belum dapat dicapai. Hal ini membuktikan bahwa terjadi perbaikan sikap dan hasil belajar ke arah yang lebih baik.

Berdasarkan persentase penguasaan materi pembelajaran Bahasa Indonesia pada siklus III mengalami peningkatan yang baik. Ini disebabkan oleh dua faktor yang mempengaruhi yaitu fakor internal dan faktor eksternal. Faktor internal meliputi pengetahuan siswa, sikap, motivasi, minat dan kondisi siswa sendiri. Adapun faktor eksternal mencakup gangguan tempat siswa belajar dan suasana kelas yang terkendali.

Pada proses pembelajaran siklus III telah ada peningkatan batas tuntas belajar, yakni ada 23 siswa atau sebesar 88,46\% dari jumlah 26 siswa mendapat nilai $\geq 65$. Ini berarti batas tuntas belajar telah terpenuhi karena jumlah siswa yang memperoleh nilai $\geq 65$ lebih dari $75 \%$. Hasil tersebut diketahui setelah diadakan analisis hasil tes formatif penguasaan materi pembelajaran Bahasa Indonesia pada siklus I, siklus II, dan siklus III.

\section{E. PENUTUP}

\section{Simpulan}

Berdasarkan hasil pembahasan pada bab IV dapat disimpulkan sebagai berikut :

1. Ada peningkatan yang signifikan pada penguasaan materi pembelajaran, hal ini dapat dibuktikan dari hasil tes formatif pada siklus I, siklus II, dan siklus III. Pada siklus III ada 23 siswa dari jumlah 26 siswa atau sebesar 
$88,46 \%$ yang memperoleh nilai $\geq 65$. Ini berarti batas tuntas belajar telah terpenuhi karena jumlah siswa yang memperoleh nilai $\geq 65$ lebih dari $75 \%$.

2. Data kualitatif yang diperoleh melalui pengamatan menunjukkan adanya perubahan perilaku siswa yang positif. Perubahan tersebut terlihat pada penguasaan materi pembelajaran, minat dan motivasi belajar, maupun hasil belajar siswa.

3. Dalam tindakan perbaikan pembelajaran dengan menerapkan metode dan alat peraga yang efektif dan optimal dapat meningkatan pemahaman siswa terhadap materi pelajaran sehingga siswa lebih aktif serius, antusias dalam menarik materi pelajaran.

4. Siswa lebih percaya diri dan berani mengemukakan pendapatnya baik dalam kelompok diskusi maupun salam, proses pembelajaran, di kelas.

5. Dengan adanya tindakan perbaikan pembelajaran ini, motivasi siswa untuk memahami dan menguasai materi pelajaran sangat tinggi, hal ini dapat dilihat dari hasil belajar siswa yang diperoleh dari siklus I, siklus II dan siklus III. Di samping itu menumbuhkan sikap siswa untuk meningkatkan belajarnya, berani mengungkapkan pendapat atau bertanya serta tidak ragu-ragu lagi dalam menghadapi berbagai persoalan materi pelajaran.

\section{Saran dan Tindak Lanjut}

Setelah melaksanakan tindakan perbaikan pembelajaran hasilnya ada peningkatan, maka penulis sarankan sebagai berikut :

1. Untuk Guru

a. Untuk meningkatkan pemahaman siswa terhadap materi pembelajaran hendaknya guru dalam mengajar lebih mengoptimalkan penggunaan media pembelajaran yang ada di lingkungan siswa, dan memilih metode yang tepat sehingga pembelajaran lebih mengesankan dan menyenangkan.

b. Guru hendaknya lebih bervariasi dalam menyajikan materi pembelajaran supaya pembelajaran tidak membosankan. 
2. Untuk Pengambil Kebijakan Pendidikan

Laporan ini dapat diajdikan bahan diskusi dalam kegiatan kelompok kerja guru serta dapat dijadikan bahan referensi untuk mengambil kebijakan. 


\section{DAFTAR PUSTAKA}

Ahmadi, 1991, Psikologi Belajar. Jakarta : Rineka Cipta

Ali, Lukman. 1995. Kamus Besar Bahasa Indonesia. Jakarta : Balai Pustaka

Arsyad, Azhar. 1994. Efektifitas Pengunaan Alat Terapi.Yogyakarta : UGM Press.

Depdikbud. 2000. Pembelajaran Bahasa Indonesia Kelas III SD. Jakarta. , 2006. Kurikulum Tingkat Satuan Pendidikan SD. Jakarta : Diksi Insan Mulia.

Haryudi. 1997. Peningkatan Ketrampilan Berbahasa Indonesia, Yogyakarta: UGM Press

Heriyanto, Hamid. 2003. Statistik Dasar. Jakarta : Universitas Terbuka

Masnur, Muslich. 2007. KTSP Pembelajaran Berbasis Kompetensi dan Konstektual. Bandung : Bumi Aksara.

Pasaribu. 1986. Didaktik dan Metodik. Bandung : Tarsito

Rusyan. 1994. Pendekatan Proses Belajar Mengajar. Bandung Remaja Rosdakarya.

Rusyanti, 2004. Cermat Berbahasa Indonesia Kelas III SD. Surakarta : Mediatama.

Sudjana. 1995. Metode dan Media Pembelajaran. Bandung : Bina Aksara

Suwandi, Kasida. 2004. Cermat Berbahasa Indonesia Kelas III. Surakarta : Mediatama.

Tarigan, 1984. Membaca sebagai Suatu Keterampilan Berbahasa. Bandung. Angkasa

Umar, Hamzah. 2000. Peningkatan Keterampilan Bahasa Indonesia. Bandung : Inti Prima Aksara

Uno, Hamzah. 2007. Teori Motivasi dan Pengukurannya. Bandung : Bumi Aksara.

Winata Putra, dkk. 1997. Strategi Belajar Mengajar. Jakarta : Universitas Terbuka.

Zaenal Aqib. 2007. Penelitian Tindakan Kelas. Bandung : Yrama Widya. 